\title{
The Bankruptcy Forecasting Model of Hungarian Enterprises
}

\author{
Aranka Baranyi ${ }^{1}$, Csaba Faragó ${ }^{1}$, Csilla Fekete ${ }^{1}$, Zsuzsanna Szeles $^{2, *}$ \\ ${ }^{1}$ Institute of Business Sciences, Eszterházy Károly University, Hungary \\ ${ }^{2}$ Institute of Business Sciences, Budapest Metropolitan University, Hungary
}

Copyright $\mathrm{O} 2018$ by authors, all rights reserved. Authors agree that this article remains permanently open access under the terms of the Creative Commons Attribution License 4.0 International License

\begin{abstract}
The SME sector is really important for the Hungarian economy. In our analysis, we had a closer look at the publicly accessible version of Altman's Z-score bankruptcy forecast model for companies not quoted on the Stock Exchange together with the original and the modified, adjusted Springate bankruptcy prediction model. The adjusted Springate model regarded only $37 \%$ of the companies having gone bankrupt in real as insolvent, while the justified Altman Z-score model was able to identify only $46 \%$ of the stable ongoing firms. The variance analysis could not detect any correlations between the phenomenon of bankruptcy and financial types. By means of logistic regression, we managed to create a model that can forecast solvency for the examined enterprises with a probability of $78 \%$. In the last part of our research, we were dealing with teaching artificial intelligence and creating decision trees based on neural network. Even by means of the first bankruptcy forecast model based on decision trees, a more efficient predicting system was gained than by using any other methods. We assume that only the decision tree made up by using artificial intelligence is efficient in forecasting bankruptcy of all the examined models.
\end{abstract}

Keywords Bankruptcy Forecasting, Enterprises, Profitability, Liquidity Indicators, Logistic Regression

\section{Introduction}

In Hungary, a significant part of the enterprises are active in the SME sector. In 2015 altogether 1.7 million enterprises were registered, of which 560000 were joint ventures, i.e. only $33 \%$. In Germany, according to the 2014 figures, $73 \%$ of the enterprises took this form.[16] In the German enterprise model, most enterprises employ fewer than 10 people, which is typical of more than $90 \%$ of them. [17] It is interesting to note that while in Germany, 81 million inhabitants possess 3.6 million enterprises. This ratio in Hungary is nearly 2 million enterprises per approximately 10 million inhabitants. [18]
In our fast moving and globalised world, enterprises are typically able to operate in constantly changing environment regardless their profile. Every business partner would like to know which enterprise is worth cooperating with so as to avoid the future problems of their winding up sometimes without any evidence of their previous operation. In addition to liquidity, long-term solvency is also a decisive factor as the lack of enough funds can result in insolvency. [19]

The early forecast of insolvency is an indispensable factor not only for banks and credit rating institutions. For an enterprise, it could be an advantage if it is able to forecast and manage the possible solvency problems of its partners in time. The objective of our research is the objective forecast of the insolvency of small-and medium-sized enterprises by means of financial indicators. Our further objective is to work out such a method that makes use of publicly accessible figures of balance sheets, profit and loss accounts to forecast a state on the edge of bankruptcy with great reliability. Nowadays bankruptcy models have become an integral part of business evaluation. [4] Our paper examines certain industries, such as construction, processing industry, accommodation and catering between 2010 and 2014. Our data were obtained from the well-known Opten Kft. operating in Hungary. Altogether 122093 companies were analysed in details, of which 48491 were in construction, 45544 in processing and 28058 in accommodation and catering, respectively. While examining solvency variance and discriminant analyses, logistic regression and artificial intelligence were used to detect any correlations.

\section{Literature Review}

Bankruptcy prediction was studied by a lot of researchers for the past years. Financial impact has been analysed from the economic, financial, accounting, statistical, organizational and informational point of view. [28] A large number of academic research papers were focusing on finding the best corporate failure prediction 
model, resulting a wide range of literature base. Fundamental factors for such development are that corporate performance has become one of the most analysed fields in finance and accounting literature which was supported by increased availability of reliable financial data and modern statistical techniques. [29]

According to Kiaupaite-Grushniene, financial failure researches could be divided into two parts: before and after 1990s. The techniques of bankruptcy prediction prior to 1990s were dominated by static single-period classification models, which attempted to find unique characteristics that differentiate between successful and failed companies. P. Fitzpatrick (1932) is considered as the first researcher to use univariate analysis in a comparison of ratios of successful and failed industrial companies. Further researches took into consideration the ability of combination of financial ratios to predict bankruptcy by Beaver (1966) and Altman (1968). [31, 32, 33]

The techniques in the 1990s concentrated more on dynamic models that would determine a company's distress risk at each point in time (Shumway, 2001). Altman and Hotchkiss (2005) focused mainly on quantitative techniques. [35]

Shumway (2001) argues that hazard models are more appropriate than single-period models for forecasting bankruptcy. Single-period models are inconsistent, while hazard models produce consistent estimates. He describes a simple technique for estimating a discrete-time hazard model. He states that about half of the accounting ratios that have been used in previous models are not statistically significant. Market size, past stock returns, and idiosyncratic returns variability are all strongly related to bankruptcy. [34]

According to Dimitras et al. (1996) this trend is rather worrying, as most of these studies focus on ability of quantitative techniques to correctly predict business failure one to five years prior to legal bankruptcy, considering that managers were unaware of the problems their companies face and were unable to take corrective actions. [29]

The process to discriminate between bankrupt and on-business companies began with Beaver in 1966 and was popularized by Altman's (1968) Z-score based on multiple discriminant analysis.

In 2007 the world financial and economic crisis increased the number of bankruptcies in countries all over the world and changed the scope and focus of researches which responds to the need to predict this phenomenon, providing both on individual country and at a global level, with explanations of the common characteristics shared by the involved companies. [36]

\subsection{Defining SMEs in Hungary}

According to Act XXXIV effective from 1 May 2004 the balance sheet total, the number of employees and the total net revenue per annum has to be considered when defining micro, small and medium sized enterprises. Enterprises with fewer than 25 employees, annual net revenue of maximum 50 million euro and its equivalent in forint or balance sheet total of maximum 43 million euro and its equivalent in forint can be regarded as SMEs. Within the SME category, micro enterprises are companies with fewer than 10 employees, and an annual net revenue or balance sheet total of maximum 2 million euro and its equivalent in forint. Small enterprises are the ones with fewer than 50 employees and an annual net revenue or balance sheet total of maximum 10 million euro or its equivalent in forint. Medium-sized enterprises are companies employing maximum 250 people with annual net revenue of 50 million euro or balance sheet total of 43 million euro. [15]

In Hungary the proportion of small and medium-sized enterprises is $99.8 \%$ of the total number of enterprises. More precisely, most enterprises are located in Budapest (31\%) while the Great Plains have the highest number of small and medium- sized enterprises. In North Hungary the number of ongoing enterprises is quite low with some percentage. [5]

As the SME sector plays a significant role in our county the Government approved the changes to improve SMEs on 7 February 2007 that make their contribution to efficiency and economic growth possible. [20] However, there are few employees in an average Hungarian SME although the volume of production would call for more. Market players define the enterprise itself ranging from customers, suppliers, creditors, owners and business partners to investors. Stakeholders receive their revenue in the form of dividends. Contacting customers and suppliers is made on an everyday basis. [14]

The SMS sector gives a better opportunity for self-fulfillment and employees feel more secure while big companies offer competitive salary. [12]

\subsection{The Most Popular National Industries between 2010 and 2014}

An essential part of the bankruptcy model is the selection of industries where fluctuation was the highest, or, at least more and more enterprises became insolvent. The figure below presents the 10 industries most likely to be threatened by bankruptcy from 2010 to 2014. [7]

On a monthly basis, we examined the ratio of bankruptcy within the industries as of the total number of enterprises of the given industry. It was concluded that although 'Electricity, gas and steam supply and air conditioning' takes the lead by $0.42 \%$, this industry had approximately 1000 enterprises between 2010 and 2014. So the number of enterprises going bankrupt per month is about 4 , which is very low for us to analyse bankruptcy models. The other two industries of the Figure are also characterised by similar data so going down the list Construction, Processing industry and Accommodation-catering were selected. These industries have several ten thousand enterprises each, which are proved as satisfactory to carry out proper analyses. 


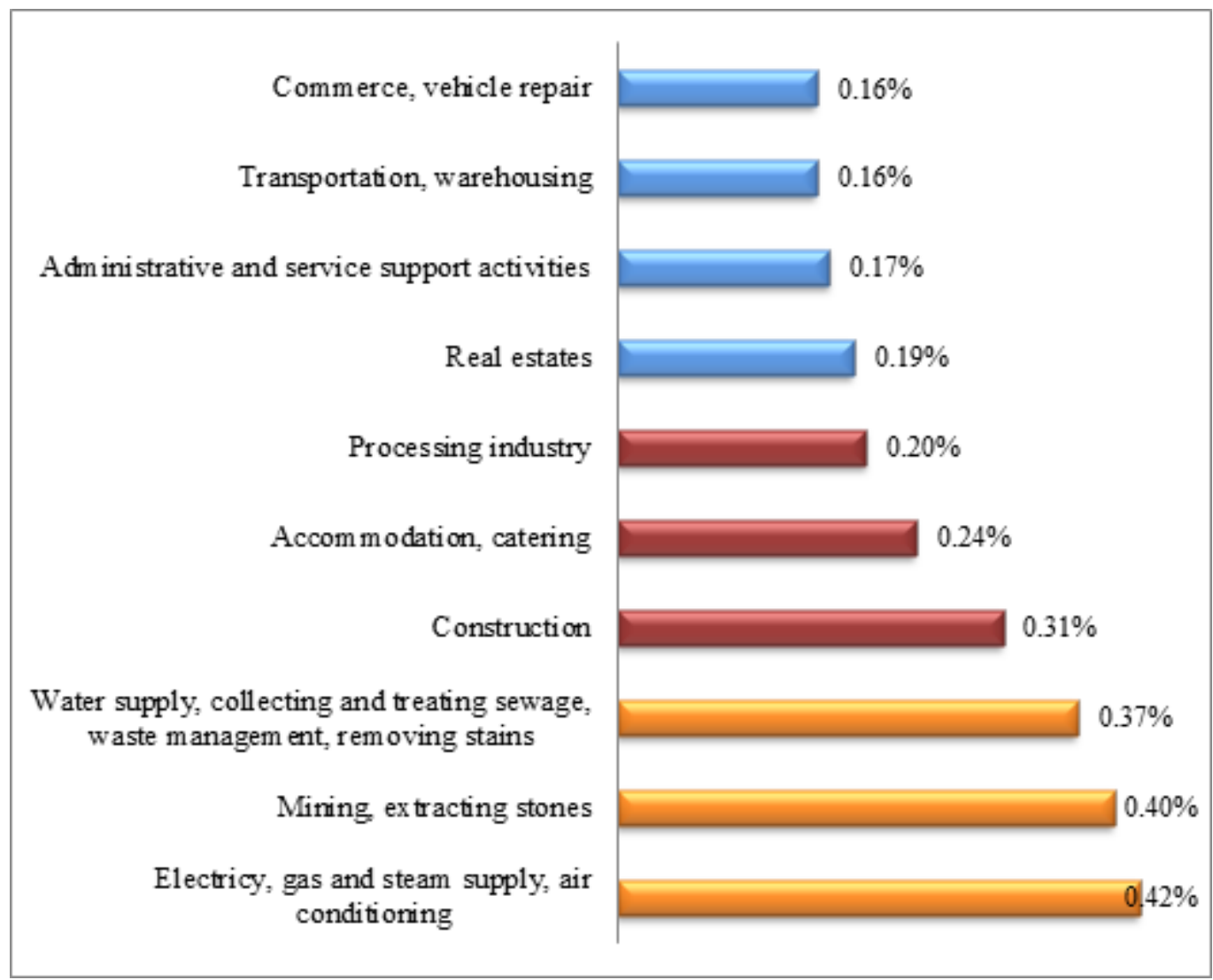

Source: Authors' own edition based on the data of the Central Statistical Office

Figure 1. The breakdown of companies going bankrupt in different industries per month between 2010 and 2014

\subsection{Construction}

The construction industry plays a very important role in the national economy. It contributes to creating jobs and boosting the economy. It is such an industry where different changes take place, such as employees do not have a fixed place to work and both the inhabitants and the environment can influence the job. Factors that have a great impact on the construction business include funds from the central budget, demand and supply of households and the general public, and also supporting and credit facilities.

Table 1. Breakdown of construction output in 2013 and 2014

\begin{tabular}{|c|c|c|}
\hline Name & $\begin{array}{c}\text { Value at current price } \\
2013 \\
\text { bn Ft }\end{array}$ & $\begin{array}{c}\text { Value at current } \\
\text { price 2014 } \\
\text { bn Ft }\end{array}$ \\
\hline Constructing buildings & 448.5 & 335.2 \\
\hline Other buildings & 562.4 & 506.2 \\
\hline $\begin{array}{c}\text { Special vocational } \\
\text { training }\end{array}$ & 763.6 & 590.5 \\
\hline Construction total & 1774.5 & 1432 \\
\hline
\end{tabular}

Source: authors' own editing based on data from epitesimegoldasok.hu [22]

The breakdown of construction output in 2013 and 2014 is presented by Table 1 .

At the beginning of the 2000 's, there were approximately 66 thousand ongoing enterprises, half of which were Ltd $(\mathrm{Kft})$ or partnerships $(\mathrm{Bt})$. Limited companies (Rt) and cooperatives then made up only a slight proportion of the registered companies. During the period between 1995 and 2005 the number of construction sites quintupled. At the same time, it also means that there was a growth of $8.3 \%$ per year as from 1997 there was a slight increase. Five percent of the employees were employed in the construction industry. [21]

It can be seen from the table above that in 2014 production value increased by nearly $15 \%$ as of 2013 , which shows an annual turnover of 2000 billion forint.

Table 2. Registered enterprises in construction between 2011 and 2014

\begin{tabular}{|c|c|c|c|c|}
\hline Number of enterprises & 2011 & 2012 & 2013 & 2014 \\
\hline Corporate & 59923 & 58710 & 56837 & 55602 \\
\hline Individual & 38519 & 36750 & 36455 & 37649 \\
\hline Total & 98442 & 95460 & 93292 & 93251 \\
\hline
\end{tabular}

Source: authors' own editing based on data from the Central Statistical Office [8] [9]

It can be seen from the table that in total the number of registered enterprises decreased during the examined period. This reduction was due to the decrease in corporate bodies (joint ventures), while the number of private proprietorships did not change significantly between 2010 and 2014. [3] In the past seven years, construction companies have lost more than half of their market share. Before the global crisis in 2008, nearly 20 thousand flats 
were built for direct sale on the market. With the limited financial means in 2013, willingness to build houses further decreased and only less than 3 million new ones were built. In 2014, 7293 new homes were constructed, which is $31 \%$ lower than in 2012 . Nowadays national construction activity has decreased by 205 and new contracts for buildings have also gone down by $24.7 \%$. [23]

Declining willingness to construct is made up by several factors. First, circular debt has been an ongoing problem for almost three years. Due to it, traders are in a more vulnerable situation as thy have liabilities towards the producers and their customers (micro-, small and medium-sized enterprises) are often unable to settle their bills due to the fact that their debtor also fails to pay them. Another great problem is that there are not enough EU funds that could be used together with the earlier introduction of the reverse charge VAT as the constructor obtains the materials with VAT while they do not charge VAT when invoicing their customers. Reclaiming VAT usually takes 3 months, which means a constant loss of 30-40 billion forint net working capital based on the calculations of the association, which is a strikingly great problem. [24] [25]

\subsection{The Processing Industry}

This industry includes assembling produced and purchased parts together with manufacturing machines and equipment. Within this sector, machinery is the growth engine and the other significant branch is microelectronics as integrated circuits and chips are used almost everywhere. It can mostly be found in areas where there is a lot of skilled labour force. The third most important part is manufacturing computers, electronic and optic products. [26]

In 2009 the volume of orders reached its lowest point ever due to the crisis. Almost $80 \%$ of the enterprises could not expand due to the low level of demand. There were few orders as a result of financing problems, as well. From the second half of 2010, the industry started to expand continuously due to the growing volume of orders. Since 1995 it was the sixth strongest rate of orders according to the Hungarian Logistics and Procurement Association. In 2013, growth was not significant, while in 2014 it had a growth of $9 \%$ as of 2013, which means 24 thousand billion forint in figures. Moreover, the processing industry also showed a significant growth. Vehicle manufacturing had its biggest share, i.e. $20.6 \%$, where a growth of $27 \%$ in 2012 and a decrease of $15 \%$ in 2013 could be experienced. The food processing industry was expanded by $4.8 \%$ and electronics by $1.3 \%$, respectively. Food industry grew by
$26 \%$ as of the previous year, i.e. 2013 while the volume of selling tobacco and beverages increased by $4.6 \%$. A growth of $5.8 \%$ in metal processing, nearly $6 \%$ in plastics and almost $16 \%$ in leather products was realized. In processing, sales export amounted to $73.4 \%$, which means a growth of $12.3 \%$ as of 2013 . Half of this derives from vehicle manufacturing and the other half from producing computers, electronic and optic products. The third largest group includes metals that showed a nearly $12 \%$ growth in 2014. Taking the regions into account there was an increase in the processing industry everywhere, but the largest one was achieved in West Transdanubia with almost $18 \%$. The number of registered enterprises in 2013 reached 72198, while in 2014-72889 was registered. Regarding employment, 1867 employees worked in the private sector whose average salary hardly increased as of 2013. In 2014, the number of employees in the energy sector was increased by $2.5 \%$ while those working in mines decreased by $0.5 \%$, when compared to the previous year. Nearly $80 \%$ of the employees in vehicle manufacturing are blue collar workers. [10]

Nearly 100 thousand employees work in the food and tobacco industry; the metal industry employs 79 thousand people while in electronics, more than $18 \%$ workers were employed in 2014 than the previous year.

\subsection{Accommodation and Catering}

Tourism is one of the most prominent parts of the national industry in addition to the fact that half a million people are employed there. The hospitality industry accounts for $5.8 \%$ of GDP and employs 360 thousand people. There are 37 thousand catering establishments officially registered providing fewer rooms. Nearly $50 \%$ of other types of accommodation can be found in the Lake Balaton touristic region, where domestic tourists dominate. Lack of skilled labour force is still a grave problem nowadays. Salaries are the lowest in the hospitality industry, i.e. gross 138 thousand forint.

In a regional breakdown, Central Hungary boasts the most catering units, i.e. 16548 followed by the North Great Plains with 6518 and West Transdanubia with 5732 while North Hungary lags behind with 5 636. In 2014 gross revenue amounted to 806 billion forint, $86 \%$ of which was engaged in commercial tourism. Between 2009 and 2014, prices remained the same in tourism; but since 2014, there has been an increase. The ratio of revenues is continuously rising from the beginning of the year, but it reaches its highest point in the summer. Table 3 summarises the changes in catering establishments between 2009 and 2014. 
Table 3. Changes in the number of catering establishments between 2009 and 2014

\begin{tabular}{|c|c|c|c|c|c|c|}
\hline Year & Restaurants & Confectioners & Entertainment & Commercial catering units & Corporate hospitality & Total catering units number of \\
\hline 2009 & 23079 & 3108 & 20379 & 46566 & 5338 & 51904 \\
\hline 2010 & 24709 & 3312 & 21511 & 49532 & 5533 & 55065 \\
\hline 2011 & 25245 & 3283 & 21529 & 50057 & 5673 & 55730 \\
\hline 2012 & 25929 & 3362 & 21033 & 50324 & 5629 & 55953 \\
\hline 2013 & 25711 & 3431 & 20253 & 49395 & 5521 & 54916 \\
\hline 2014 & 25344 & 3508 & 19065 & 47917 & 5469 & 53386 \\
\hline
\end{tabular}

Source: authors' own editing based on data from trademagazin.hu [26]

It can be seen from the table that the hospitality industry has continuously been on the rise since 2009. Of the commercial units mentioned above, the most popular ones are the commercial establishments, while the proportion of corporate hospitality units is the slightest. However, the number of confectioners rose significantly between 2009 and 2014. Ranking by profile has been changed for products consisting of statistical activities and the products most typical of them. In 2009, West Hungary had the highest demand for accommodation. At that time, hardly more than 3000 registered enterprises were recorded. In 2010 turnover slightly decreased, but still Transdanubia was the most popular. The number of guest nights spent at higher quality establishments increased in 2010 while decline could be experienced in the lower categories. In the accommodation sector, more than 168 thousand people were employed in 2014 and revenues nearly reached 360 billion forint. In 2014, almost 10 million guests were registered, which is hardly more than in the previous year. In the hospitality industry, there were 13 thousand joint ventures almost all ranked as small or medium sized enterprises. Within the SME sector, the proportion of micro enterprises is $89 \%$, while that of small enterprises amounts to $10 \%$ and medium-sized enterprises accounted for only $1 \%$ in 2013. The $27 \%$ VAT can be stated as the highest in Europe. According to 2017 plans the situation of the catering units will be made more favourable by decreasing it to $18 \%$ in the case of non-alcoholic beverages and from 2018 it will be reduced to only $5 \%$. [6]

\section{Materials and Methods}

It was considered a vital part of our research that all data were gained from publicly available balance sheets and profit and loss accounts. But it was our desire to carry out the analyses on a database with more samples, so assistance from Opten $\mathrm{Kft}$. was required. Due to the representative nature of the analysis, entire industries were to be analysed so that randomly selected parts of the pattern should not distort the results. The selection of industries was based on data from the Central Statistical Office between 2010 and
2014. The database consisted of approximately 16 million-record-files, of which 122093 companies could be analysed: 48491 in construction, 45544 in processing and 28058 enterprises in accommodation and catering, respectively,

The financial indicators of each enterprise were defined for the database such as bankruptcy indicators and bankruptcy forecasting, profitability, liquidity indicators, capital intensiveness, indebtedness indicators, financing strategies.

In our research, the Altman Z-score bankruptcy model as well as the original and modified (adjusted) Springate bankruptcy prediction were analysed in more details as it was only them that could be defined on the basis of the publicly accessible balance sheets and profit and loss accounts. In the first step of the analysis, descriptive statistics were applied to define the structure of population. By using SPSS statistical programme package examinations were conducted to explore different correlations. [11] Variance analysis was applied to define the relation between bankruptcy and the types of enterprises. Categorical bankruptcy forecasting values were produced by means of discriminant analysis and logistic regression from metric data and the authors also attempted to produce discriminant functions of their own.

In the final part of our research, possibilities of predicting bankruptcy are explored by using neural network. To this end, RGui software was used in which instructions must be given in R language. C5.0 educating algorithm was used to teach artificial intelligence which is more developed than the previous $\mathrm{C} 4.5$ version. It is able to cut back decision trees, which is a great help when optimising findings. (Lanz, 2013)

\section{Results}

Of the 48491 enterprises in construction examined in the 5 years, 9954 went bankrupt, which is $21 \%$ of the companies. The remaining 38537 did not go bankrupt till the end of 2014. The proportion of the 45544 enterprises analysed in the processing industry is approximately $16 \%$, 
which accounts for 7469 companies. The number of companies that did not go bankrupt is 38075 accounting for $84 \%$ of the entire industry. Of the 28058 enterprises in accommodation and catering, the number of companies going bankrupt is 6335 between 2010 and 2014, i.e. $23 \%$ of the industry and the remaining $77 \%$, i.e. 21723 did not at all go bankrupt.

Illustrating bankruptcy per year, we can state that the threat of bankruptcy decreased in the examined period and the analysed enterprises became more stable.

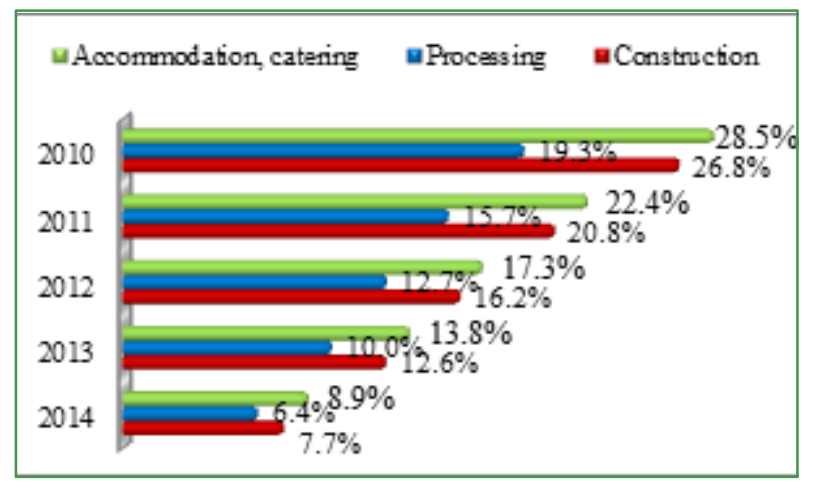

Source: Authors' own edition based on research database

Figure 2. Changes in bankruptcy per year in the selected industries between 2010 and 2014

Furthermore, we also analyse how well bankruptcy predicting models can forecast the chances of the analysed companies' going bankrupt. Of the bankruptcy forecast indicators used the Springate model was examined in the processing industry with more details where the probability of bankruptcy was the lowest. Only $37.85 \%$ of the 7449 enterprises having gone bankrupt in real were predicted. At the same time, however, $41.37 \%$ of them were forecast as solvent, which can be regarded as a serious mistake.

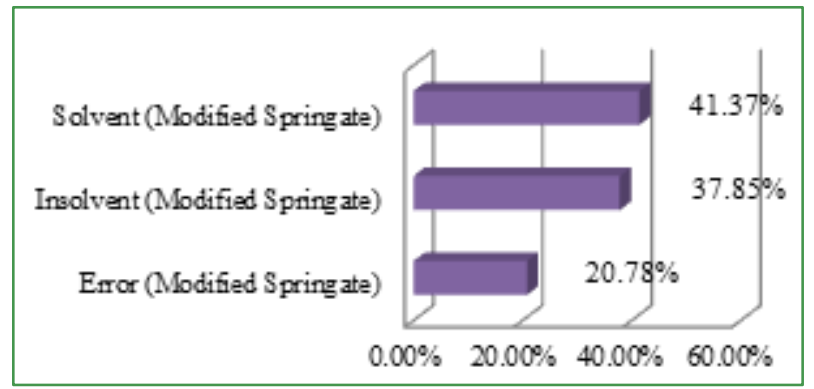

Source: Authors' own edition based on research database

Figure 3. The Springate forecast of enterprises going bankrupt in the processing industry between 2010 and 2014

However, it must be mentioned that the error rate is quite high, i.e. around $20 \%$. It happens when an enterprise has such financial values, on the basis of which forecasts cannot be calculated, e.g. if the total assets of the company or its own capital is zero. They are, however, only extreme cases. Examining these enterprises with more details, it can be seen that such a scenario takes place when the company is on the edge of bankruptcy.
We also had a closer look at the ongoing firms. As stated previously, the Altman Z-score model was also unable to produce good results here by having signalled only $46 \%$ of the enterprises as solvent.

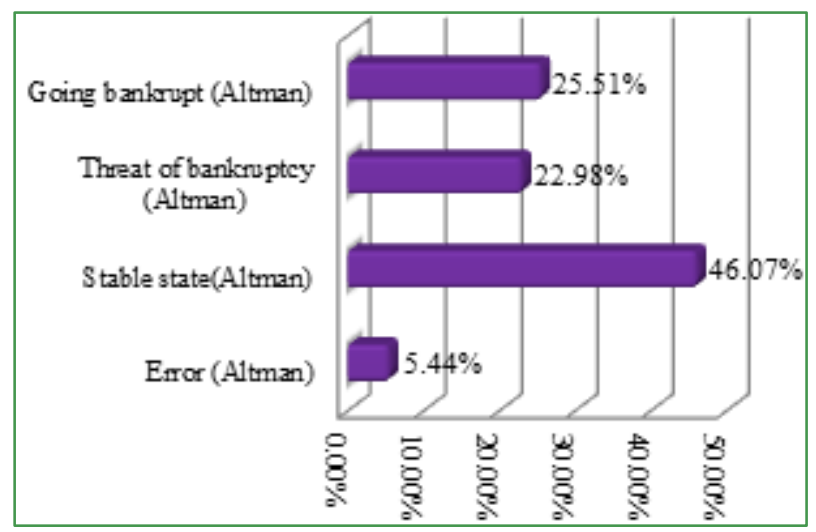

Source: Authors' own edition based on research database

Figure 4. Bankruptcy forecast of solvent enterprises in the processing industry by using the Altman Z-score model between 2010 and 2014

\subsection{Detecting Correlations between Variables by Variance Analysis}

Our research was carried out by using SPSS statistical software package. To detect the correlations between the variables one-way ANOVA variance analysis was used [Analyse $\rightarrow$ Compare Means $\rightarrow$ One-Way ANOVA], through which bankruptcy was correlated with the financial type indicators of enterprises. At first, examining preconditions was necessary, which could be carried out by using the Levene test of SPSS [Options $\rightarrow$ Statistics $\rightarrow$ Homogeneity of variance test] that examines homogeneity. Several variables were opted out in the test as the null hypothesis of the Levine test proved to be true, i.e. there was no significant difference between the means. Due to the result of the Levene test, only the variables where the significance level reaches 0.05 were kept. In this case, these financial indicators only include ROE and cash liquidity. Univariate variance analysis was carried out with them [Options $\rightarrow$ Statistics $\rightarrow$ Descriptive]. The level of significance of the $\mathrm{F}$ trial is higher than 0.05 in every case. That is why the null hypothesis was accepted, i.e. there was no significant difference between the single variables.

\subsection{Logistic Regression Calculation and Discriminant Analysis}

Our research so far has not resulted in any findings so the methods originally used for predicting bankruptcy in the 1960's and 1970's were used by the constructors of the original bankruptcy model. First, logistic regression was applied [Analyse $\rightarrow$ Regression $\rightarrow$ Binary Logistic]. As a categorical data, the fact of bankruptcy itself was regarded as the dependent variable while the financial types functioning as metric data were considered as the 
independent ones. Before the use of logistic regression the confidence interval of the contribution of variables together with its probability had to be marked [Options $\rightarrow$ Statistics and Plots $\rightarrow$ CI for $\exp (\mathrm{B})]$, which is basically $95 \%$.

Table 4. The classification table of the logistic regression of accommodation and catering in 2010

\begin{tabular}{|c|c|c|c|}
\hline \multicolumn{4}{|c|}{ Classification table $^{2}$} \\
\hline \multirow{3}{*}{ Observed } & \multicolumn{3}{|c|}{ Predicted } \\
\hline & \multicolumn{2}{|c|}{ BANKRUPTCY } & \multirow{2}{*}{$\begin{array}{c}\text { Percentage } \\
\text { Correct }\end{array}$} \\
\hline & No & YES & \\
\hline BANKRUPCY - NO & (10511) & 52 & 99.5 \\
\hline BANKRUPCY - YES & 2812 & 61 & 2.1 \\
\hline Overall Percentage & & & 78.7 \\
\hline
\end{tabular}

${ }^{a}$ The cut value is .500

Source: Authors' own editing based on research database

Based on the classification, table below gained as a result the status of solvency for a company can be predicted with a certainty of $78.7 \%$ by using logistic regression. However, if we have a closer look at the result, it can be noticed that this proportion is so good because the prediction is only made for companies not going bankrupt, which is $99,5 \%$. Measuring and forecasting bankruptcy is not so accurate at all as only in $2.1 \%$ of the cases could bankruptcy be predicted.

During our research, it was our intention to make our own discriminant functions made up by the financial indicators calculated by us. To this end, the discriminant analysis of SPSS had to be used [Analyse $\rightarrow$ Classify $\rightarrow$ Discriminant]. A lot of conditions must be met to carry out the analysis. As a categorical data, the fact of bankruptcy itself was regarded as the dependent variable, while the financial types functioning as metric data were considered as the independent ones. Not even discriminant analysis was able to separate firms by metric data. Based on the calculated financial types, the solvent companies and the ones having gone bankrupt were put together in the same group. It means that there is no unified, standard discriminant function for the given set, i.e. the entire industry. We were trying to reduce the number of samples in the set, believing that SPSS might be able to create a model for a set of fewer samples as Altman, Springate, Fulmer, Virág etc. made up their bankruptcy model by making experiments with a few (50-100) companies. At first, we tried to have 10000,1000 , and then 100 samples but in vain. [1] [2] [13]

This reducing process was also carried out by using logistic regression and the gained results were improving. We saw that with 100 samples bankruptcy forecast works with a reliability of more than $85 \%$. This is far better than the data included in Table 4. As a matter of fact, it is much more important to forecast the enterprises that finally go bankrupt. However, no valid conclusions can be drawn due to the low number of samples. The classification table of the logistic regression of the 129 -member pattern is displayed by Table 5 .

Table 5. The classification table of the logistic regression of the accommodation and catering industry with reduced number of samples

\begin{tabular}{|c|c|c|c|}
\hline \multicolumn{4}{|c|}{ Classification table $e^{x}$} \\
\hline \multirow{3}{*}{ Observed } & \multicolumn{3}{|c|}{ Predicted } \\
\hline & \multicolumn{2}{|c|}{ BANKRUPTCY } & \multirow{2}{*}{$\begin{array}{c}\text { Percentage } \\
\text { Correct }\end{array}$} \\
\hline & No & YES & \\
\hline BANKRUPCY - NO & 53 & 8 & 85.5 \\
\hline BANKRUPCY - YES & 9 & 53 & 86.6 \\
\hline Overall Percentage & & & 86.0 \\
\hline
\end{tabular}

${ }^{\text {a }}$ The cut value is .500

Source: Authors' own editing based on research database

The other two industries were also analysed by using the methods for statistical correlations mentioned before. The data of several years were analysed, but due to the limitations of this study they are not presented now as there were no significant differences from the previous ones.

\subsection{Research by Using Artificial Intelligence}

Artificial intelligence creates decision trees by means of the so-called recursive partitioning. This method is based on breaking down data into smaller and similar groups. At the root of the tree that represents the entire dataset, the algorithm will select the attribute that best defines the target group. Then, the data are classified on the basis of the different values of the attribute above, which will make the first branching of the tree. The algorithm will go on with applying this method at every top by selecting the best attribute. The 32-bit-version of the RGui software was used to examine neural networks in which the instructions are given in $\mathrm{R}$ language. As the first step, the data file and the data structure was read. Data were divided into two parts: a greater student dataset and a smaller set where the decision trees made by the process of studying are checked. First, the database was randomly mixed and $80 \%$ of the basic set went into the student set, i.e. 118645 cases and the remaining 20\% was set aside for the time being. Further operations called for a de facto industrial standard, i.e. the C5.0 algorithm, which gave relatively simple and mostly proper solutions. C5.0 algorithm compiled a decision tree of 104 levels, which can be stated as relatively high although the correctness of the forecast was not impacted substantially. Of the 118645 cases and 100028 solvent companies, the decision tree classified 98688 enterprises properly, which is a ratio of $98.7 \%$. This figure is surprisingly good. However, of the 18617 companies that went bankrupt, only 2360 enterprises were identified properly, which is a ratio of $12.7 \%$. Numerically, the forecasting ratio of the model is $85 \%$, which can be regarded well. The list of parameters used for creating the decision tree is presented by Table 6 . Due to the constraints of length and other limitations, the variables that influence 
the creation of the decision tree in less than $5 \%$ are opted out. It can be seen that the most important parameters include total asset, pre-tax profit and own capital. Each of these parameters showed a value of over $90 \%$ while the decision tree was compiled.

Table 6. The list of parameters used for the decision tree of the construction industry

\begin{tabular}{|l|l|}
\hline Attribute usage: & \\
\hline $\mathbf{1 0 0 . 0 0} \%$ & Total assets \\
\hline $\mathbf{9 0 . 5 1} \%$ & Pre-tax profits \\
\hline $\mathbf{9 0 . 2 6} \%$ & Own capital \\
\hline $\mathbf{5 7 . 0 8 \%}$ & Altman_X5 \\
\hline $\mathbf{3 3 . 7 1 \%}$ & Funds \\
\hline $\mathbf{3 2 . 0 5 \%}$ & Extra profit \\
\hline $\mathbf{9 . 5 0} \%$ & Balance sheet profit \\
\hline $\mathbf{8 . 9 7 \%}$ & Current assets \\
\hline $\mathbf{8 . 2 4} \%$ & Net profit from sales \\
\hline $\mathbf{7 . 5 2} \%$ & Capital intensiveness \\
\hline $\mathbf{5 . 4 7 \%}$ & Long-term liabilities \\
\hline
\end{tabular}

Source: authors' own editing based on the research database

To continue our research, errors of the complied decision tree were weighed as providing a non-solvent client with credit could result in huge losses. The ratio of the false positive ones can be reduced by rejecting the values on the border. A possible few years' interest loss causes slighter damage than non-payment. C5.0 algorithm provides the opportunity to 'punish' different errors, so the algorithm is forced to make fewer costly errors. For that purpose, a cost matrix was used. This matrix shows how many times one error is costlier than the other. Based on our literature review, the 1:4 ratio was selected for the cost matrix dealt by Brett Lant in more details. It means that defaulted credit costs four times as much for the bank as a credit opportunity not taken. The decision tree is able to identify enterprises based on solvency in $78 \%$. We could reckon it is a step back from the previous model as this ratio used to be $85 \%$. But this model is able to identify whether an enterprise went bankrupt in real with a ratio of $78.4 \%$. This is a giant leap from the $12.7 \%$ value of the previous model. Furthermore, we also examined the ratio of forecasting insolvency based on unknown data by our compiled decision tree on the basis of the cost matrix. The model was intended to be improved by modifying the ratio of cost matrix from 1:4 to 1:5. The forecasting ability of the model was further decreasing after modifying the cost matrix down to $66 \%$, while bankruptcy increased to $65.5 \%$ so the punctuality of forecasting increased by $9 \%$.

On the basis of the forecasts run, the decision tree was able to predict outcome in $74 \%$ and it gave proper forecasts on insolvency in $56.6 \%$. Our results are summarised by a diagram presented by Figure 5. To sum up, it can be stated that our models succeeded in classifying an examined enterprise in 62-74\% of the cases. In the case of bankruptcy, these models show values between 57 and $68 \%$.

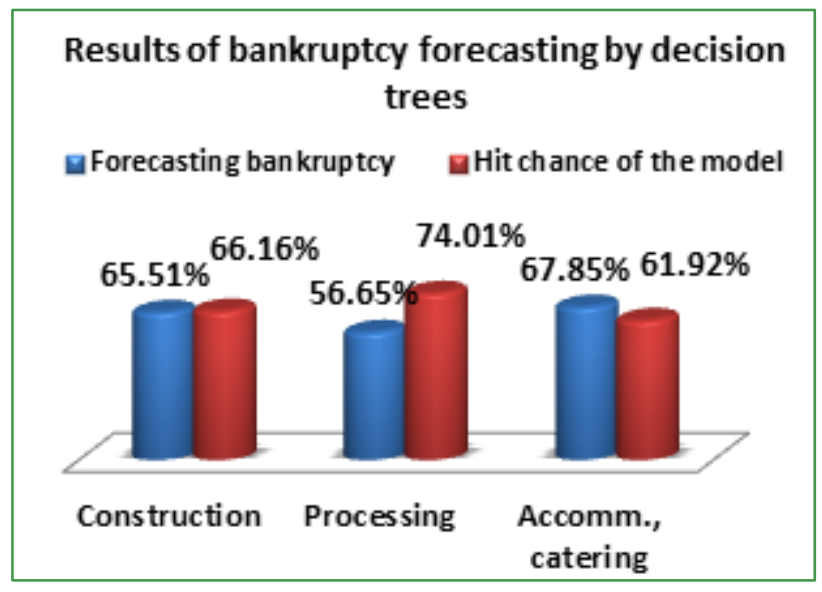

Source: authors' own editing based on the research database

Figure 5. The results of the bankruptcy forecasting model by decision trees between 2010 and 2014

Based on our examinations, the punctuality of forecasting bankruptcy is weakening with the reduction of the real ratio of going bankrupt. However, our model managed to find out the solvency category of an enterprise with a higher degree of certainty, accordingly. It can derive from the fact that with the passage of time, the number of companies going bankrupt decreases so the system works with a smaller database and there are fewer companies that went bankrupt. As a result, it is more difficult for the C5.0 algorithm to create a proper decision tree. 


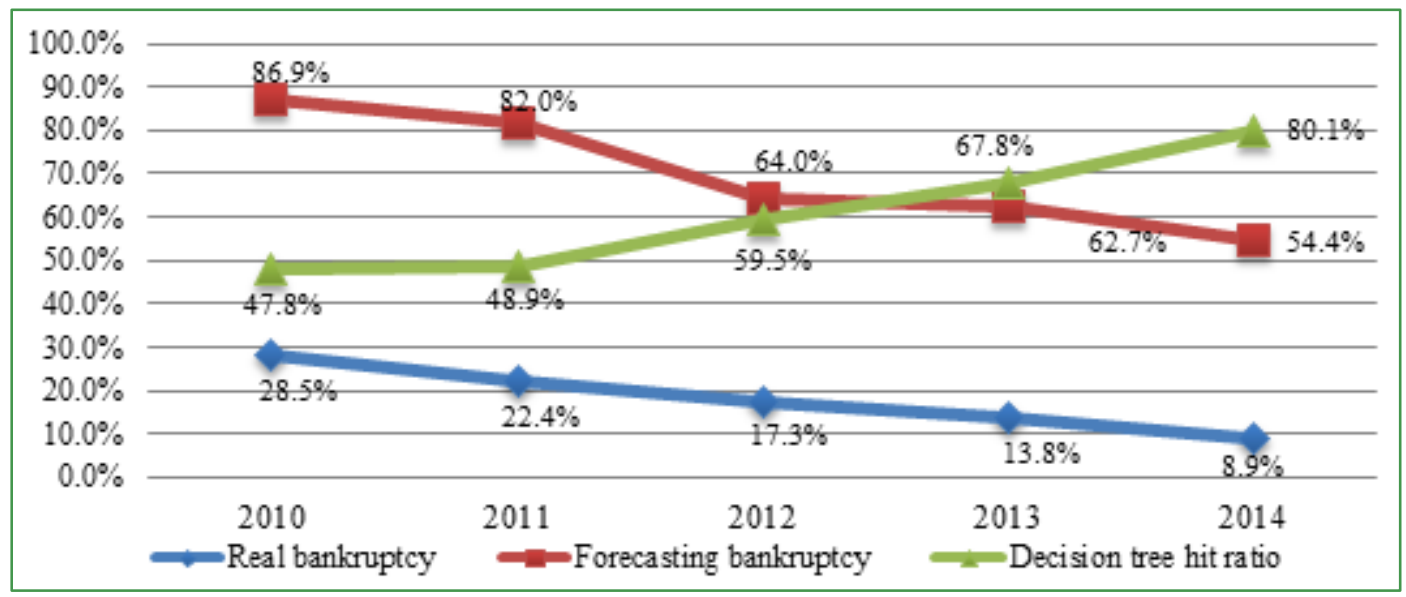

Source: Authors' own editing based on research database

Figure 6. Forecasting bankruptcy per year between 2010 and 2014

In the end, we also examined how the created decision trees can be constant and how they are able to forecast bankruptcy with the passage of time. We were astonished when experiencing that as years pass, the efficiency of our bankruptcy models also deteriorates. In practice, a decision tree from 2010 has become outdated to date. It is too strict in forecasting insolvency. Based on current data, a decision tree of 1-2 years old can bring good results in forecasting bankruptcy while efficiency is getting weaker as years go by.

\section{Conclusions}

Even before selecting the topic of our current research, we had some doubts in connection with the smooth running of bankruptcy forecast indicators created by using discriminant analysis in the 1960's and 1970's on the grounds of our previous research. In our analysis we had a closer look at the publicly accessible version of Altman's Z-score bankruptcy forecast model for companies not quoted on the Stock Exchange together with the original and the modified, adjusted Springate bankruptcy prediction model. In the three examined industries (construction, processing industry and accommodation-catering), we have concluded that the error rate of the models is not only high but they are unable to forecast either the state on the edge of bankruptcy or insolvency properly. The adjusted Springate model (performing much better than the original one after improving the weighed parts) regarded only $37 \%$ of the companies having gone bankrupt in real as insolvent while the justified Altman Z-score model was able to identify only $46 \%$ of the stable ongoing firms. To conclude, the bankruptcy prediction of bankruptcy indicators with different parameters of earlier research is not only deteriorating, rather, it has become unusable by now as they are unable to follow the changes of the recent years.

In the second part of our research by using SPSS statistical software package, we tried to point out the correlations between the variables and find a possible connection. The variance analysis could not detect any correlations between the phenomenon of bankruptcy and financial types. By means of logistic regression, we managed to create a model that can forecast solvency for the examined enterprises with a probability of $78 \%$. However, this model is too benevolent and regards $98 \%$ of the companies having gone bankrupt in real as solvent and this efficiency rate is not acceptable. By using discriminant analysis we tried to create our own discriminant functions but the SPSS programme was unable to carry it out and separate the groups from our data. The examinations went on by reducing the number of samples and situations with few models were reproduced, which was also employed when creating all the bankruptcy forecast models by renowned researchers. This did not help in creating discriminant functions, either but by working with a reduced number of samples (129). We succeeded in making up a surprisingly good bankruptcy model with a probability of $85 \%$. However, no far-reaching conclusions were drawn due to the low volume of samples and random sampling as the results are not of representative nature.

In the third part of our research, we were dealing with teaching artificial intelligence and creating decision trees based on neural network. Even by means of the first bankruptcy forecast model based on decision trees, a more efficient predicting system was gained than by using any other methods. We also had the possibility of further optimisation by means of a cost matrix in which certain errors were punished more strictly. Depending on the industries, our models are able to identify the enterprise with a certainty of $62-74 \%$. When forecasting bankruptcy these models work at approximately $57-68 \%$.

We also examined the time constancy of our own models. We can state that in the examined industries the existing bankruptcy models can predict insolvency 1-2 years before without significant errors, but for a period of 4-5 years it is totally unacceptable. While dealing with descriptive statistics, it was stated that during the examined period the 
chances of going bankrupt went down with the passage of time in all selected industries. Based on this, the results of model creation and the usefulness of our bankruptcy forecast were examined. It can be concluded that in parallel with the decrease in the number of bankruptcies the indicators are even worse and worse.

We assume that only the decision tree made up by using artificial intelligence is efficient in forecasting bankruptcy of all the examined models. It can also be concluded that for few samples (100), it is not possible to make such a bankruptcy forecast that could be applied widely. To make a good model in real, more and more data and bankruptcy events are necessary.

\section{Acknowledgements}

We thank our colleagues, Dr. Péter Racskó and Dr. Tamás Novák for his support in applying artificial intelligence in finance.

\section{REFERENCES}

[1] E. Altman: Predicting financial distress of companies: Resvisiting the Z-score and Zeta ${ }^{\circledR}$ Models. New York University, 1-54, 2000

[2] B. Lantz: Machine Learning with R. Packt Publishing, 1-396, 2013

[3] A. Baranyi, Cs. Faragó, Cs. Fekete: A KKV vállalkozások pénzügyi típusjelenségeinek vizsgálata a kutatás-fejlesztés tükrében, Acta Carolus Robertus No.12, 7-21, 2016

[4] P. Gyurcsik., L. Pataki: A finanszírozás controlling funkciói a kkv-k jövedelmezőségének szemszögéből. Controller Info No.4, 35-39, 2016

[5] L. Gyulai: A kis- és középvállalkozások üzleti finanszírozása. Saldo Kiadó, 1-168, 2013

[6] Hungarian Statistical Office, Online available from http://www.ksh.hu/docs/hun/xftp/idoszaki/jeltur/jeltur15.pd f

[7] Hungarian Statistical Office, Online available from https://www.ksh.hu/docs/hun/xstadat/xstadat_evkozi/e_qvd 012a.html

[8] Statisztikai Szemle, Online available fromhttp://www.ksh.h u/statszemle_archive/1999/1999_09/1999_09_732.pdf

[9] Hungarian Statistical Office, Online available from http://www.ksh.hu/docs/hun/xftp/gyor/gaz/gaz21012.pdf

[10] Hungarian Statistical Office, Online available from http://www.ksh.hu/docs/hun/xftp/gyor/ipa/ipa21412.pdf

[11] L. Sajtos, A. Mitev: Kutatási és adatelemzési kézikönyv. Alinea Kiadó, Budapest, 1-404, 2007

[12] I. Szántó: Számvitel alapja. Perfekt Kiadó, Budapest, 1-388, 2013
[13] M. Virág: Pénzügyi elemzés csődelőrejelzés. Kossuth Kiadó, Budapest, 1-302, 1996

[14] A. Reizingerné Ducsai, M. Vörös: Könyvviteli Alapismeretek. Perfekt Kiadó, Budapest, 141-159, 2005

[15] 2004. évi XXXIV. Law about Small- and medium size anterprises, their development support

[16] Farkfurter Allgemeine Wirtschaft, Online available from http://www.faz.net/aktuell/wirtschaft/

[17] Statista, Online available form https://de.statista.com/statis tik/daten/studie/237346/umfrage/unternehmen-in-deutschla nd-nach-rechtsform-und-anzahl-der-beschaeftigten/

[18] Demographische Entwicklung, Online available from http://www.ipicture.de/daten/demographie_deutschland.ht $\mathrm{ml}$

[19] GeVestor: Liquiditat - für Unternehmen die luft zum Atmen, Online available form http://www.gevestor.de/deta ils/liquiditat-fur-unternehmen-die-luft-zum-atmen-657853. html

[20] J. Varga.: A kis- és közepes vállakozói helyzet Magyarországon. Tudományos Közlemények, No.27., 239-256. Online availballe from http://epa.oszk.hu/02000/ 02051/00027/pdf/EPA02051_Tudomanyos_Kozlemenyek 27_2012_aprilis_239-256.pd

[21] Az építőipar helyzete és az építési piac térbelisége, Online available from http://docplayer.hu/4619653-Az-epitoipar-h elyzete-es-az-epitesi-piac-terbelisege.html

[22] A Magyar építoiipar számokban, Online available from https://epitesimegoldasok.hu/admin/data/file/10496 a-mag yar-epitoipar-szamokban-es-a-2015-evi-vara.pdf

[23] Durva visszaesés az építóiparban, Online available from http://hir6.hu/cikk/119169/durva_visszaeses_az_epitoiparb an

[24] Magyar Nemzet, Online available from http://mno.hu/migr 1834/visszaeses az epitoiparban-2927 17

[25] Brutálisan visszaesett az építőipari termelés, Online available from http://24.hu/fn/gazdasag/2016/03/16/brutali san-visszaesett-az-epitoipari-termeles

[26] Az ipar ágazatai, Online available from http://tudasbazis.sulinet.hu/hu/termeszettudomanyok/foldr ajz/tarsadalomfoldrajz/szekunder-szektor-ii-az-ipar/az-ipar -agazatai

[27] A vendéglátás ágazat statisztikai helyzetértékelése - 2016, Online available from http://www.trademagazin.hu/horeca/ 82791.html

[28] V. Kiaupaite-Grushniene: Altaman Z-Score Model for Bankruptcy Forecasting of the Listed Lithuanian Companies, 5th International Conference on Accounting, Auditing, and Taxation, Atlantic Press, 222-234, 2016

[29] A. Dimitras., S. Zanakis, C. Zopoudinis: A Survey of business failures with an emphasis on failure prediction methods and industrial applications, European Journal of Operational Research, Vol. 90, 487-513., 1996

[30] P. Fitzpatrick: A comparison of ratios of successful 
industrial enterprises with those of failed firms, Certified Public Accountant, Vol.2, 598-605, 1932

[31] J. W. Levins: The Effect of Smaller Firms Size and Change in Firm Size on Altman's Revised Bankruptcy Prediction Model. Ph. D thesis, Nova Southeastern University. Available from: ProQuest, 1997

[32] W. Beaver: Financial ratios as predictors of failure, Journal of Accounting Research, Vol.4, Empirical research in accounting: Selected studies, 71-111, 1966

[33] E. Altman: Financial ratios, Discriminant analysis and the prediction of corporate bankruptcy. The Journal of Finance, vol. XIII, no. 4, pp. 589-609, 1968

[34] T. Shumway: Forecasting Bankruptcy More Accurately: A Simple Hazard Model, The Journal of Business, Vol.74, No.1, 101-24, 2001

[35] E. Altman, E. Hotchkiss: Corporate Financial Distress and Bankruptcy: Predict and Avoid Bankruptcy, Analyse and Invest in Distressed Debt, 3rd ed. US: John Willey and Sons, 2006

[36] D. Alaminos: A Global Model for Bankruptcy Prediction, PLoS ONE 11(11): e0166693. doi:10.1371/journal.pone.0 166693, 2016 